\title{
Orthopedic Department of Education Center and Service Provide During Coronavirus Disease-2019 Pandemic: An Experience from Single-Center Hospital
}

Bagus Jati Nugroho ${ }^{1}$, Bintang Soetjahjo ${ }^{1}$, Udi Heru Nefihancoro ${ }^{1}$, Rieva Ermawan ${ }^{1}$, Rhyan Darma Saputra ${ }^{1}$, Galih Santoso Putra ${ }^{2}$, Fathih Kaldani $^{3 *}$, Muhammad David Perdana Putra ${ }^{2}$, Zaltri Rhani Lebang ${ }^{2}$, Dea Alberta Setiawati ${ }^{2}$

${ }^{1}$ Department of Orthopaedic, Sebelas Maret University, Surakarta, Central Java, Indonesia; ${ }^{2}$ Resident of Surgery Department, Sebelas Maret University, Surakarta, Central Java, Indonesia; ${ }^{3}$ Resident of Orthopaedic Department, Sebelas Maret University, Surakarta, Central Java, Indonesia

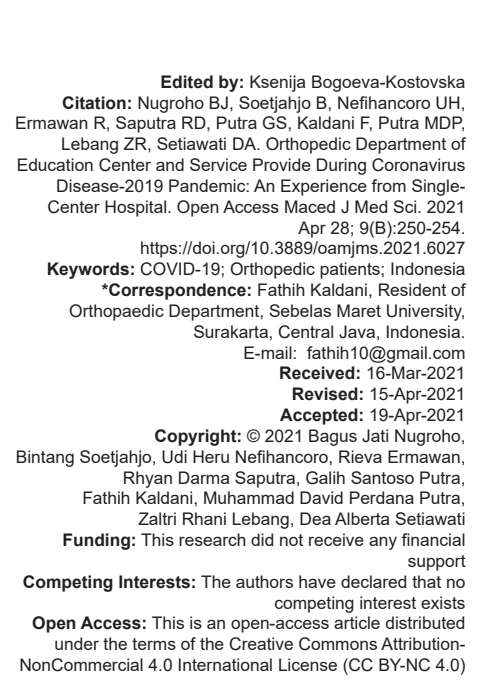

Abstract

BACKGROUND: In the global pandemic of the 2019 coronavirus disease (COVID-19), many countries have reported a decrease in visits to hospitals, and health-care systems around the world are reshaping health protocols. Health service and education in orthopedics are also affected although not at the frontline in dealing COVID-19.

AIM: We aimed This article reports how Dr. Moewardi general hospital as tertiary referral hospitals deal with this complicated situation.

METHODS: The data from this study collected from several official databases, including the Indonesian Ministry of Health, Central Java provincial government, general hospital, and orthopedic surgery cases.

RESULTS: Pandemic COVID-19 started in March 2020 in Indonesia. Surakarta has become one of the epicenters. Health services in the orthopedic department also experienced a decrease cases on all divisions (outpatient clinics, emergency rooms, and inpatients). Mann-Whitney non-parametric comparative test showed significance result in $p$ value operation of orthopedic cases and inpatients $(p=0.016$ and $p=0.016 ; p<0.05)$, meanwhile, outpatient visits did not show significance result with $p=0.0509(p>0.05)$. The decrease in the number of cases being treated in the orthopedic service also has an impact on education and training programs. The digital era is one of the choices in the field of education. However, digital resources cannot substitute for direct patient exposure.

CONCLUSION: The average number of orthopedic patients during the pandemic period from January to December 2020 decreased compared to visits in the same period in 2019 so that orthopedic services at tertiary and academic referral hospitals experienced a significant decrease in cases. The education and services department must adapt to the policy on educational activities for residents and medical students. The education department and hospital institutions restructured and reorganized resident doctors to continue providing services. The digital era is an option that supports the education process during a pandemic.

\section{Background}

Coronavirus disease (COVID-19) is an infectious disease that occurs due to the acute respiratory tract infection due to coronavirus-2 severe acute respiratory syndrome coronavirus 2 . Indonesia has become one of the most impacted countries by pandemic COVID-19. The first case was found in March 2, 2020, and immediately increased dramatically. The World Health Organization (WHO) declared COVID-19 as an epidemic in early March 2020. Due to those declaration, the President of Indonesia also signed Government Regulation No. 21/2020 to implement large-scale social restrictions to control the spread of the disease in March 2020 [1], [2], [3], [4].

The restrictionsincludebanning closing schools, non-public service office, mass gatherings, restricting public transportation, and restricting non-essential businesses. The Ministry of Health also appointed certain hospitals as referral hospitals for dealing with developing infectious diseases. Dr. Moewardi General Academic Hospital has been appointed to cover the pandemic in Central Java province [5].

Dr. Moewardi Regional General Hospital is located in the province of Central Java, a type A hospital in Indonesia, and designated by the government as a tertiary referral hospital. Dr. Moewardi Regional General Hospital has supporting facilities for handling COVID such as intensive care unit (ICU), isolation ward for patient with infectious diseases, tertiary referral hospital, and the main academic affiliated hospital of the Sebelas Maret University, Faculty of Medicine, Surakarta. The hospital provides a high volume of health-care services for a wide range of many cases. The hospital also serves as the premier academic affiliated hospital for an education and training center for junior medical students and 
multispecialty residency education program. However, during pandemic, all of these functions must adapt to new situations. Orthopedic services and education are no exception.

Several publications discussed the management of services and education to overcome the current situation, especially the COVID-19 pandemic. This article reports how Dr. Moewardi general hospital as tertiary referral hospitals deal with this complicated situation. We explain the impact of the outbreak, adapted hospital policies, orthopedic patient care by comparing outpatient visits, surgical patients, and monthly inpatients during the period of JanuaryDecember 2020 (early pandemic period) compared to the same period in 2019. We explain educational programs during the outbreak and also planning for future reference on service readiness and education.

\section{Methods}

We process the data to evaluate trends in orthopedic services from the number of outpatient visits, surgical patients, and monthly orthopedic inpatients from January to December 2020 (during the pandemic period) compared to the same period in 2019 and analyzed separately. Data were taken from the database of Dr. Moewardi Hospital Health Information System. Data from 1 year before the outbreak were included in the study. We intend to give our readers a clearer picture about the impact of the outbreak. During a pandemic, only procedures necessary to live saving are permitted. The priority of the lifesaving procedure is divided to urgent and emergency. Emergency cases were defined as cases requiring immediate treatment to the emergency and/or operating room (hemodynamically unstable pelvic fracture, crush injury, and multiple open fractures).

\section{Results}

In mid-November 2020, the Indonesian government had confirmed 59,911 active COVID19 cases with an increase (4106 cases) of $12.83 \%$, death rate $3.26 \%$, new cases average of $19.76 \%$ in October, and increase in the number patients recovering (recovered cases) after the latest confirmed COVID-19 cases. Central Java province is one of the regions with high COVID-19 cases. In November 2020, theses province had recorded 5723 cases as cumulative active cases, while in comparison with Jakarta, which had documented 6600 cases. From the results of the study, data show that the highest percentage of confirmed cases based on age distribution is in the $31-45$ years age group (26.95\%). The main comorbidities of COVID-19 patients were diabetes mellitus and hypertension.

Dr. Moewardi Hospital is a government hospital. The COVID-19 pandemic is forcing hospital management to implement new protocols in the provision of health services. Orthopedic services are affected indeed and can be seen by the number of outpatient visits, surgical patients, and inpatients. The impact of this new protocols included a reduction in outpatient visits, surgical procedures (especially elective surgeries), and inpatients.

Statistical data were analyzed using the non-parametric comparative Mann-Whitney U-test. Analyzes were performed using the Statistical Package for the Social Sciences (SPSS) for Windows version 25.0, produced by IBM in New York, USA. The results of the patients number difference were statistically calculated and considered significant if $p<0.05$

\section{Outpatients visits}

The average number of outpatient visits per month during the pandemic period from January to December 2020 was 93 visits per month, a decrease compared to 108 visits in the same period in the previous year. However, the Mann-Whitney non-parametric comparative test was not significant with $p=0.509$ (Table 1). The lowest outpatient visits occurred in May 2020 with the number of outpatient visits as many as 35 patients. The number of monthly outpatient visits is shown in Figure 1.

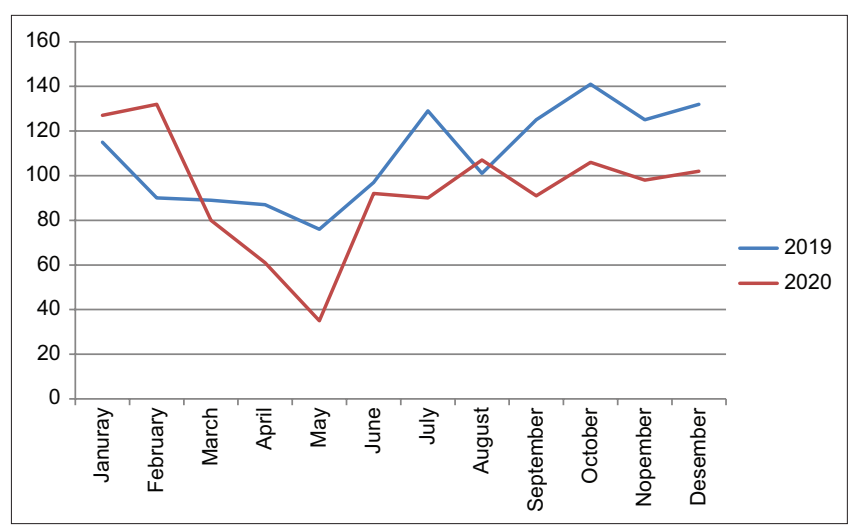

Figure 1: Outpatient visits

\section{Operation of orthopedic cases}

The number of operations of orthopedic cases performed has also decreased. Based on the data collected, there was an average of 72 operations per month in 2020 , compared to the same period in the previous year an average of 83 operations per month. The lowest number of orthopedic operations occurred in May 2020 with the number of operations in as many 
Table 1: Outpatient visits

\begin{tabular}{|c|c|c|c|c|c|c|c|c|c|c|c|c|c|}
\hline Year & JAN & FEB & MAR & APR & MAY & JUN & JUL & AUG & SEPT & OCT & NOV & DES & $p$ value \\
\hline 2019 & 115 & 90 & 89 & 87 & 76 & 97 & 129 & 101 & 125 & 141 & 125 & 132 & 0.509 \\
\hline 2020 & 127 & 132 & 80 & 61 & 35 & 92 & 90 & 107 & 91 & 106 & 98 & 102 & \\
\hline
\end{tabular}

Table 2: Orthopedic cases operation

\begin{tabular}{|c|c|c|c|c|c|c|c|c|c|c|c|c|c|}
\hline Year & JAN & FEB & MAR & APR & MAY & JUN & JUL & AUG & SEPT & OCT & NOV & DES & $p$ value \\
\hline 2019 & 76 & 64 & 76 & 63 & 75 & 74 & 91 & 97 & 102 & 103 & 94 & 84 & 0.016 \\
\hline 2020 & 96 & 82 & 78 & 38 & 32 & 67 & 69 & 76 & 93 & 84 & 90 & 60 & \\
\hline
\end{tabular}

as 32 patients, from the results of the Mann-Whitney non-parametric comparative test, significant results were obtained with $p=0.016(p<0.05)$. The number of monthly orthopedic surgery patients is shown in Figure 2 and Table 2.

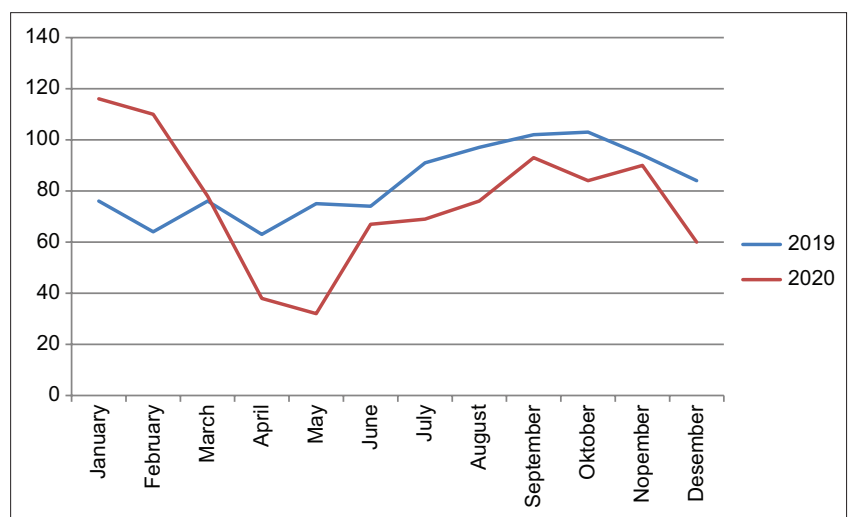

Figure 2: Orthopedic cases operations

\section{Inpatients}

Inpatient at Dr. Moewardi patients with orthopedic cases, based on the results of the nonparametric comparative Mann-Whitney U-test data on inpatients at the Regional General Hospital Dr. Moewardi, showed a statistically significant decrease $(p<0.05)$ 0.016 . Based on Table 3, it can be seen that the number of hospitalized patients was higher in the pre-pandemic period compared to the pandemic period (Figure 3).

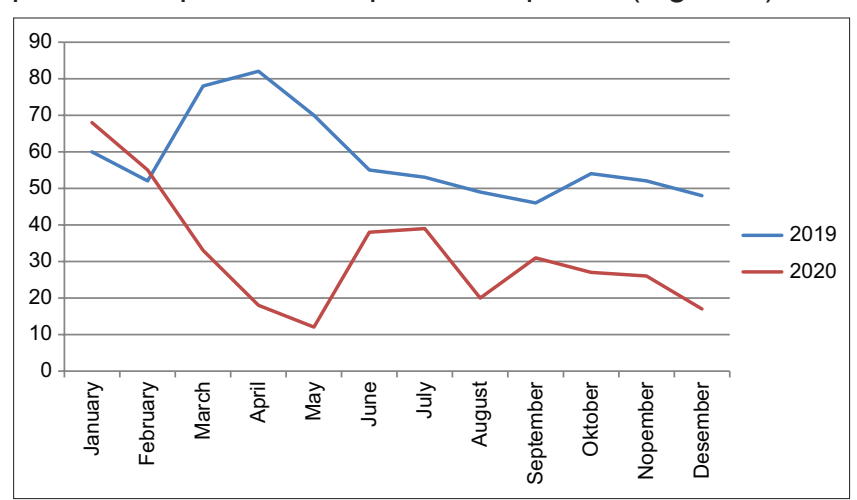

Figure 3: Inpatients

The decrease in the number of polyclinic visits, inpatients, and orthopedic surgery cases had a direct impact on the experience of resident physicians. Restructuring and reorganizing residency education in rotational settings was done to avoid exposure to COVID19. On the other side, there is a new educational structure introduced with digital educational teleconference. The head of the residency study program rearranges residents shift for hospital services (Figure 4). Residents are divided into three teams, an emergency team, an elective team, and a team that learns and works from home. Elective team performs elective surgeries and outpatient clinic, and off duty after that. Emergency team is in charge of emergency patients during that day and work from home the next day (third team).

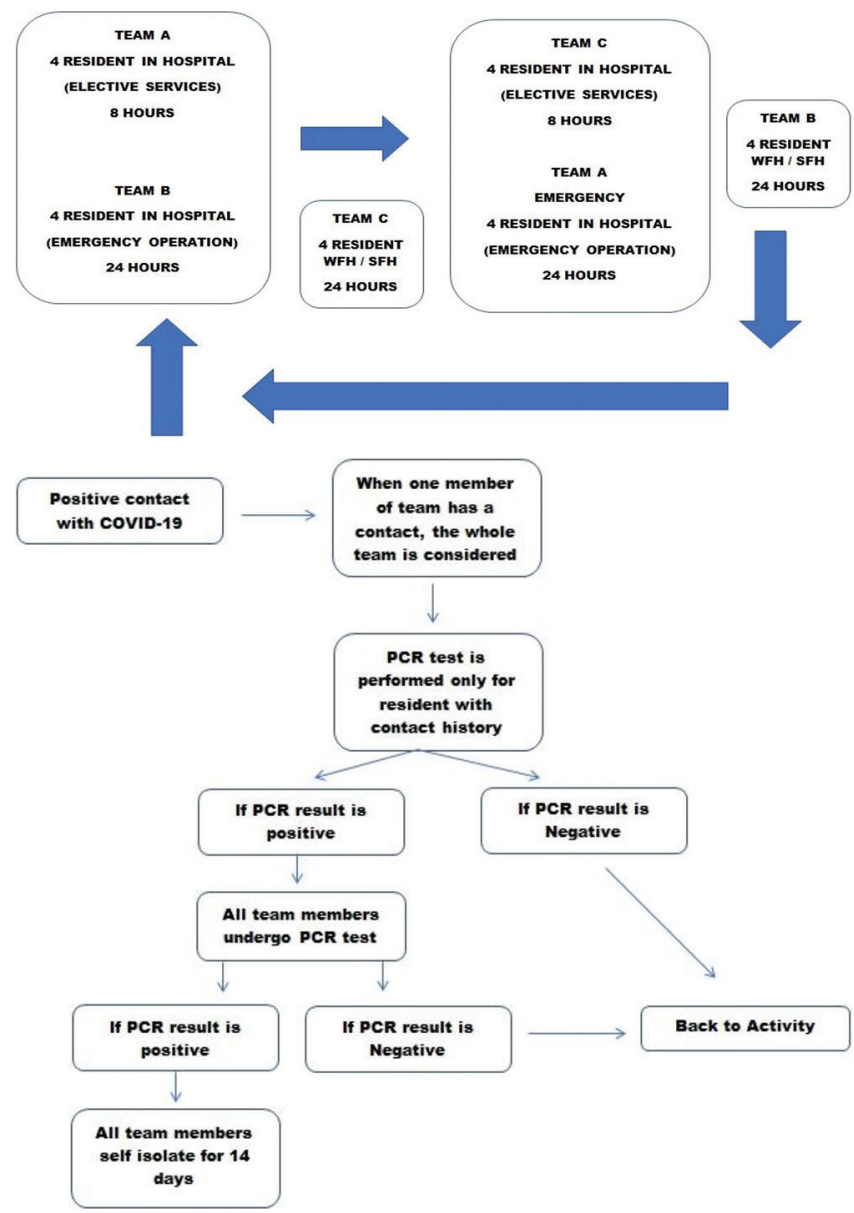

Figure 4: Resident shift regulation during pandemic

\section{Discussion}

The impact of COVID-19 in orthopedic services is very real and in line with the regulations of government boards of directors and hospitals. Dr. Hospital Moewardi as a tertiary referral hospital is 
Table 3: Inpatients

\begin{tabular}{|c|c|c|c|c|c|c|c|c|c|c|c|c|c|}
\hline Year & JAN & FEB & MAR & APR & $\mathrm{MEI}$ & JUN & JUL & AUG & SEPT & OCT & NOV & DES & $p$ value \\
\hline 2019 & 60 & 52 & 78 & 82 & 70 & 55 & 53 & 49 & 46 & 54 & 52 & 48 & 0.016 \\
\hline 2020 & 68 & 55 & 33 & 18 & 12 & 38 & 39 & 20 & 31 & 27 & 26 & 17 & \\
\hline
\end{tabular}

restructuring its resources to accept more cases of COVID.

The hospital had sufficient isolation space to accommodate COVID-19 patients in early March 2020. As cases continued to increase, the number of isolation rooms was increased. The consequence of room restructuring was a decrease in the surgical ward capacity and ICU availability for elective surgery.

At hospital entry points (outpatient clinics and emergency rooms), screening for the risk of COVID-19 infection is applied, and a screening of early warning score was performed for all incoming patients (Table 4). All swab polymerase chain reaction (PCR)-positive patients followed the confirmed COVID-19 protocol. Patients who will undergo surgery are examined by a PCR swab test.

\section{Table 4: Early warning system of COVID-19}

\begin{tabular}{|c|c|c|}
\hline \multicolumn{3}{|l|}{ COVID-19 early warning score (COVID-19 EWS) } \\
\hline Parameter & Assessment & Score \\
\hline Signs of pneumonia on computed tomography scan thorax & Yes & 5 \\
\hline $\begin{array}{l}\text { A history of close contact with a patient who has been } \\
\text { confirmed positive for COVID-19 }\end{array}$ & Yes & 5 \\
\hline Fever & Yes & 3 \\
\hline Age & $>44$ years & 1 \\
\hline Gender & Male & 1 \\
\hline Highest body temperature $(\operatorname{Tmax})^{a}$ & $>37.8^{\circ} \mathrm{C}\left(100^{\circ} \mathrm{F}\right)$ & 1 \\
\hline $\begin{array}{l}\text { Respiratory symptoms (including dry cough, cough with } \\
\text { phlegm, and shortness of breath) }\end{array}$ & $>1$ symptoms & 1 \\
\hline $\mathrm{NLR}^{\mathrm{b}}$ (neutrophil-lymphocyte ratio) & $>5.8$ & 1 \\
\hline The patient is highly suspected of COVID-19 if the score & & $>10$ \\
\hline
\end{tabular}

Appropriate personal protective equipment (PPE) is applied to all activities in outpatient clinics, wards, and operating rooms. Comprehensive training was conducted on how to clean, store, and check PPE in the early phases of the outbreak. A patient requiring emergency procedures is brought to the emergency room [6], [7], [8], [9], [10], [11], [12], [13], [14].

Based on the results of our study, it shows that in January-December 2020 during the COVID-19 pandemic period, there was a decrease in the number of visits of outpatients, surgery patients, and inpatients in each month compared to the number of visits in the same period the previous year. Based on the results of the non-parametric comparative test, significant results were obtained $(p<0.05)$ in number of surgeries and inpatients during the pandemic period compared to the pre-pandemic period.

Decreased number of orthopedic patients at Dr. Moewardi General Hospital can also because of the Decree of the Mayor of Surakarta Number 443.76/28 of 2020 concerning the Determination of the Status of COVID-19 Extraordinary Events in the City of Surakarta. This had led to a decrease in outpatient visits from March to April in 2020.
The significant reduction in orthopedic services did impact the direct clinical exposure and study experience of the resident doctors. Nevertheless, this pandemic opens up new means of education for junior doctor students and resident doctors to become part of the digital era. Online medical lectures such as webinars, teleconferences, and digital learning resources are growing exponentially. Face-to-face meetings were replaced and adapted to teleconference meetings. This has an impact on the clinical experience of the resident doctor but also opens up invaluable opportunities for the resident doctor to discuss the case broadly. However, digital methods cannot replace clinical experience and real surgical operative experience.

The university holds non-physical meetings for students. Students have reduced their doctor-patient direct clinical experience during their medical studies. To overcome this dilemma, there is a new learning system that divides into two parts. The first has been implemented during the COVID-19 pandemic phase to include student knowledge and simulation experience. The latter part is expected to occur after the hospital environment is deemed safer for educational purposes (Figure 5).

\begin{tabular}{|c|c|}
\hline \multicolumn{2}{|c|}{$\begin{array}{c}\text { Junior Doctor } \\
\text { (Undergraduated) } \\
\text { Medical Elective Rotation }\end{array}$} \\
\hline 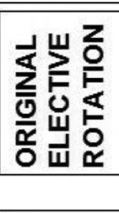 & $\begin{array}{l}\text { - Knowledge } \\
\text { - Clinical pathway } \\
\text { - Bedside teaching } \\
\text { - Problem Based Learning (PBL) } \\
\text { - Surgery observer at elective } \\
\text { operation room }\end{array}$ \\
\hline  & $\begin{array}{l}\text { - Knowledge via digital } \\
\text { - Clinical posting simulation via } \\
\text { digital } \\
\text { - PBL digital } \\
\text { - No surgery observer }\end{array}$ \\
\hline 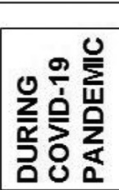 & $\begin{array}{l}\text { - Knowledge via digital } \\
\text { - Clinical posting } \\
\text { - PBL via digital } \\
\text { - No surgery observer } \\
\text { - Bedside teaching }\end{array}$ \\
\hline
\end{tabular}

Figure 5: Junior doctor (undergraduated) medical elective rotation

\section{Conclusion}

Dr. Moewardi Academic Tertiary Referral Hospital was influenced by the implementation of health protocols during COVID-19 pandemic. Orthopedic services were decreased in number of cases in 
outpatients, operations, and inpatients. Universities and study program heads must adapt to the health protocol policies for the learning continuity. Reorganization of resident doctors in providing services following health protocols was imposed by universities and hospitals. The digital era is an option during a pandemic to support the education process.

\section{References}

1. Indonesian Ministry of Health. Dua Pasien Positif COVID19 Dirawat di RSPI Sulianti Saroso. Indonesian Ministry of Health; 2020. Available from: https://www.kemkes.go.id/article/ view/20030200009/dua-pasien-positif-covid-19-dirawat-di-rspisulianti-saroso.html. [Last accessed on 2021 Mar 10]. https:// doi.org/10.34305/jikbh.v9i1.72

2. Government of Central Java Province. Penetapan Status Tanggap Darurat Bencana Corona Virus Desease (Covid-19) di Provinsi Jawa Tengah No. 360/3/Tahun 2020, Government of Central Java Province; 2020.

3. Indonesian Ministry of Health. Pedoman Pembatasan Sosial Berskala Besar Dalam Rangka Percepatan Penanganan Corona Virus Disease 2019 (COVID-19) (Guidelines for LargeScale Social Restrictions in Order to Accelerate Handling of COVID-19), Permenkes 9/2020. Indonesia: Indonesian Ministry of Health; 2020. https://doi.org/10.15408/sjsbs.v7i8.16550

4. Government of Central Java Province. Antisipasi Risiko Penularan Corona Virus Disease (COVID-19) Pada Area Tempat Kerja, Fasilitas Umum, dan Transportasi Publik di Jawa Tengah Decree of the Governor of Central Java Province No. 440/0006405, Government of Central Java Province; 2020. https://doi.org/10.24832/papua.v11i1.262

5. Indonesian Ministry of Health. Penetapan Rumah Sakit Rujukan Penanggulangan Penyakit Infeksi Emerging Tertentu (Referral Hospital for Management of Specific Emerging Infectious Disease). Decree of the Indonesian Minister of Health No. KH.01.07/MENKES/169/2020, Indonesian Ministry of Health; 2020.

6. Wen J, Qi X, Lyon KA, Liang B, Wang X, Feng D, et al. Lessons from China when performing neurosurgical procedures during the coronavirus disease 2019 (COVID-19) pandemic. World Neurosurg. 2020;138:e955-60. https://doi.org/10.1016/j. wneu.2020.04.140

PMid:32344132

7. Lee ZD, Yeu DL, Ang BT, Ng WH, Seow WT. Editorial. COVID19 and its impact on neurosurgery: Our early experience in Singapore. J Neurosurg. 2020;133(1):24-5. https://doi. org/10.3171/2020.4.jns201026

PMid:32302993

8. Burke JF, Chan AK, Mummaneni V, Chou D, Lobo EP, Berger MS, et al. Letter: The Coronavirus disease 2019 Global pandemic: A neurosurgical treatment algorithm. Neurosurgery. 2020;87(1):E50-6. https://doi.org/10.1093/neuros/nyaa116 PMid:32242901

9. Yuen J, Xie F. Medical education during the COVID19 pandemic: Perspectives from UK trainees. Postgrad Med J. 2020;96(1137):432-3. https://doi.org/10.1136/ postgradmedj-2020-137970 PMid:32371404

10. Wong RY. Medical education during COVID-19: Lessons from a pandemic. BC Med J. 2020;62(5):171.

11. Hilburg R, Patel N, Ambruso S, Biewald MA, Farouk SS Medical education during the Coronavirus disease-2019 pandemic: Learning from a distance. Adv Chronic Kidney Dis. 2020;27(5):412-7. https://doi.org/10.1053/j.ackd.2020.05.017 PMid:33308507

12. Daroedono E, Siagian FE, Alfarabi M, Cing JM, Arodes ES, Sirait RH, et al. The impact of COVID-19 on medical education: Our students perception on the practice of long distance learning. Int J Community Med Public Health. 2020;7:2790-6. https://doi.org/10.18203/2394-6040.ijcmph20202545

13. Lucey CR, Johnston SC. The transformational effects of COVID19 on medical education. JAMA. 2020;324(11):1033-4. https:// doi.org/10.1001/jama.2020.14136

PMid:32857137

14. Kim JW, Myung SJ, Yoon HB, Moon SH, Ryu H, Yim JJ. How medical education survives and evolves during COVID-19: Our experience and future direction. PLoS One. 2020;15(12):e0243958. https://doi.org/10.1371/journal. pone. 0243958

PMid:33338045 